\title{
OUT OF AFRICA \\ ACQUAINTANCE AND JOINT VENTURES WITH EDIT FARKAS DESCRIBED IN AN UNSCHOLARLY WAY
}

\author{
Tamás Pócs \\ Department of Botany, Institute of Biology, Eszterházy Károly University, \\ H-3324Eger,Pf. 43, Hungary; colura@upcmail.hu
}

Pócs, T. (2019): Out of Africa. Acquaintance and joint ventures with Edit Farkas described in an unscholarly way. - Studia bot. hung. 50(2): 293-297.

Edit Farkas started to make her $\mathrm{PhD}$ thesis under my supervision in the early 1980s at the Institute of Ecology and Botany of the Hungarian Academy of Sciences. She had chosen a very good topic, the air pollution indication of our capital Budapest, by the aid of presence or absence of lichen species. In Hungary before, there were only two attempts to use lichens as air quality indicators, by FELFÖLDY (1942) in and around the town of Debrecen and by GALLÉ (1979) in the town of Szeged. The severe pollution level of Budapest this time due to the overwhelmingly used coal heating in households and industry actualised the research. During these years I became acquainted with her very diligent and precise working style, which resulted already in her diploma work and later in her thesis and other publications (FARKAS 1982, 1990, FARKAS \& VERSEGHY 1985, VERSEGHY \& FARKAS 1985), mapping the air pollution zones, emphasised by the indicator lichen species.

But I was able to know her really better, as a personality, during the time we spent together in field work in East Africa, Tanzania, several times during the years from 1985 to 1991 . The fieldwork was organised by the Swedish aid program for developing countries (SAREC), supervised by the Botany Department of Uppsala University in cooperation with the Hungarian Academy of Sciences and by the Forestry Faculty of Sokoine University of Agriculture, Morogoro, Tanzania, called Usambara Integrated Rain Forest Project (Iversen 1988). Its aim was to make an inventory of the plants and fungi of the Usambara Mountains (and partly of the Nguru Mountains). In the Usambara Mountains since a century the encroachment of forest areas, to obtain terrain for tea and cardamom plantations and for small scale farming, has highly endangered the former very rich tropical rainforest vegetation and flora, being one of the richest African centre of biodiversity (RODGERS \& HOMEWOOD 2008). In addition, the deforested 
areas were then exposed to the loss of fertile soil layer due to the high level of soil erosion. Even the local farmers lost the fertility of their lands in great areas due to the unconsidered land use.

The field team always consisted of 2-3 Scandinavian, 1-2 Tanzanian, and 2-3 Hungarian botanists, namely Prof. Attila Borhidi, myself, and Edit Farkas. From the Hungarian group Attila Borhidi was responsible to collect and identify the vascular plants, me the bryophytes and Edit the lichenised fungi. Our participation was important, as the Scandinavian and Tanzanian participants were specialised only in the flowering plants. During the fieldwork we had approached an area in a 4-wheel drive car on the scarce road system in the mountains then made long walking and climbing tours, several times lasting for more than one day in tented camps, to explore the hidden, still intact rainforest areas or even to survey the impact of agriculture and forestry on them. In the latter case, foliicolous lichens and bryophytes proved to be very good indicators of the level of disturbance (Pócs 1989). During the work, lasting for six years, we established the actual state of all forest reserves and listed the vascular and cryptogamic plants of the area, inviting also other botanists in the inventory and identification work (e.g. Professors Hildur Krog, Ryszard Ochyra and Halina Bednarek Ochyra, furthermore even zoologists, as Sándor Mahunka, Sándor Peregovits, András Zicsi). The work resulted in numerous publications (for example Borhidi \& Pócs 1982, Borhidi \& Verdcourt 1990, Farkas 1987, 2015b, FAR Kas \& Fla Kus 2010, FARKas \& Pócs 1991, 1997, FAR Kas \& VĚZda 1993, Iversen 1988, 1991, Mahunka 1986, 1988a, $b, 1989$, Ochyra \& Pócs 1985, Pócs 1985, 1988, 1991a, b, SWINSCOW \& Krog 1986, 1988, VĚZdA 2004, VĚZDA \& FARKAS 1988, ZiCsi 1996).

During this fieldwork in the Usambara and Nguru Mountains in eastern Tanzania the long travel and walks and silent evenings under the Southern Star gave the opportunity for intimate discussions among the team members. Edit told many interesting things about her life, her family, and studies. She admired her father's talent, being an art teacher and engraver. Surely she inherited her drawing talent from him (she used to illustrate her publications by her own drawings). It was a real shock for her (between the times she stayed in Tanzania) when her believed father passed away and she suffered from his loss for long time. She told us the story of her acquaintance with her husband, László Lőkös, (also good lichenologist), in the freshmen's incentive camping during the beginning of their university studies. She explained a lot from her working methods unknown for us, especially the chemical investigations of lichen substances. She learned a lot from the worldwide known lichenologists, like the Moravian Antonin Vězda, the German Robert Lücking, the Dutch Harrie Sipman, the Norwegian Hildur Krog, and even the already retired, late Hungarian Klára Verseghy, with whom she 
maintained personal connections and vivid correspondence. She was very quick to apply new methods, even with the usual difficulties in our country to obtain expensive instruments or chemicals.

The silent camping evenings in the Usambaran rainforests were not always quiet: once we were awaken by the attack of a swarm of safari ants (species of Dorylus, kind of fire ants, called "siafu" in Kiswahili) dropping from the canopy of trees and immediately invading our bodies. The only escape was to throw off all clothes and run away. Nothing escaped her attention. It was typical for her good eye that looking a tree-frog, she immediately recognised, that its colour pattern imitates foliicolous lichens, as a very good mimicry among the leaves of rainforest bushes (FARKAS \& Pócs 1991). Edit was always very helpful, collecting not only specimens of her group, the lichens, but helping all of us in other plants as well (many bryophyte specimens bear her name as collector) and helping in all other ways, like cooking, cleaning and preparing the specimens. She has a good sense of African humour and very much enjoyed the inscriptions on the back of long distance trucks and buses or the names of roadside lodges, like the one called "Just Imagine!" on the Morogoro - Dar es Salaam highway or the adobe in the Usambara Mountains named "British Airways Hotel" with an awesome lion depicted on its wall. Taking in account all the above, she was one of the most useful and kindest member of the research group. I am convinced that her participation in the Usambara Rainforest Project was determinant on her later interest and scientific career.

After our return from Tanzania she became the secretary of the Botanical Committee of the Biology Section of the Hungarian Academy of Sciences, under my chairmanship between 1993 and 1996 and even after, with interruptions, altogether for almost 20 years. Her secretary work was characterised by full accuracy, reliability, and helpfulness. She organised the meetings well in time, recorded properly the minutes, and took all measures voted by the committee members and by the chairman.

She also organised a very successful international symposium in 1995 at the Botany Department of the Eger College on the epiphyllous cryptogams, with the participation of the leading scientists of this subject, like S.R. Gradstein (Utrecht, Göttingen), P. W. Richards (Cambridge), W. B. Schofield (Vancouver), E. Sérusiaux (Liège), A. Vězda (Brno), and many others. The results were published in a thick volume (FARKAS \& Pócs 1997). In another book (FARKAS 2007) she provided up to date knowledge on lichenised fungi for a wider, not only specialist reading public and later she defended her DSc degree summarising her multidisciplinary activities in this field (FARKAS 2015a).

Actually she is leading a small research group, raised several students, built up a proper lichenological laboratory, and carries on internationally recognised, 
up to date research. I wish her further success in the scientific career and happiness in the family life.

Összefoglaló - A rendhagyó visszaemlékezésben Pócs Tamás mutatja be megismerkedésüket Farkas Edittel. Betekintést nyújt a Tanzániába szervezett kutatóexpedíciókba, melynek mindketten résztvevői voltak 1985. és 1991. között. Ezek háttere és főbb eredményeinek ismertetése mellett kitér kettejük későbbi együttmüködésére és Farkas Edit szakmai közéleti tevékenységeire is.

\section{REFERENCES}

Borhidi A. \& Pócs T. (1982): Alapozó kutatások az ökológiai potenciál felméréséhez fejlődő trópusi országokban. - MTA Biol Oszt. Közl. 25: 437-447.

Borhidi A. \& Verdcourt B. (1990): New species of Rubiaceae-Psychotriae from Tanzania. Kew Bulletin 45: 703-710. https://doi.org/10.2307/4113882

FARKAS E. (1982): Légszennyezödési vizsgálatok Budapest területén zuzmó-bioindikátorkkal. - MSc thesis at Eötvös Lóránd University, Budapest, $91 \mathrm{pp}$.

FARKas E. (1987): Foliicolous lichens of the Usambara Mountains, Tanzania I. - Lichenologist 19(1): 43-59.

FARKAS E. (1990): Lichen mapping in the Budapest Agglomeration Area (Hungary). - Stuttgarter Beitr. Naturk. Ser. A 456: 59-65.

FARKAS E. (2007): Lichenológia - a zuzmók tudománya. - MTA Ökológiai és Botanikai Kutatóintézete, Vácrátót, $193 \mathrm{pp}$.

FARKAS E. (2015a): A lichenológiai kutatások aszpektusai - a bioindikáció, a biodiverzitás és a kémiai diverzitás összefüggései. - MTA doktori értekezés tézisei. Budapest-Vácrátót, $24 \mathrm{pp}$.

FARKAS E. (2015b): Foliicolous lichen collections on Mount Kanga, Tanzania (East Africa). - Acta Bot. Hung. 57(1-2): 41-50. https://doi.org/10.1556/abot.57.2015.1-2.7

FARKAS E. \& FLAKUS A (2016): Trichonectria calopadiicola sp. nov. (Hypocreales, Ascomycota): the second species of the family Bionectriaceae parasitic on foliicolous lichens discovered in Tanzania. - Phytotaxa 278(3): 281-286. https://doi.org/10.11646/phytotaxa.278.3.8

FAr Kas E. \& Pócs T. (1991): Foliicolous lichen-mimicry of a rainforest treefrog? - Acta Bot. Acad. Sci. Hung. 35: 73-6.

FARKAS E. \& Pócs T. (1997): (eds.): Cryptogams in the phyllosphere: systematics, distribution, ecology and use. - Abstracta Botanica 21: 1-216.

FARKAS E. \& V̌̌ZDA A (1993): Five new foliicolous lichen species. - Folia Geobot. Phytotax. Praha, 28: 321-330. https://doi.org/10.1007/bf02853518

FELFöldy L. (1942): A városi levegő hatása az epiphyton-zuzmóvegetációra Debrecenben. - Acta Geobot. Hung. 4(2): 332-349.

GALLÉ L. (1979): Wirkung der Luftverunreinigung auf die Verarmung der Flechtenvegetation der Stadt Szeged und ihrer Umgebung. - Acta Biologica (Szeged) 25(1-2): 3-15.

IVERSEN S. T. (1988): The SAREC supported Integrated Usambara Rain Forest Project, Tanzania. Report for the perid 1983-1987. - Department of Systematic Botany, Uppsala University, 93 pp.

Iversen S. T. (1991): The Usambara Mountains, NE Tanzania: phytogeography of the vascular plant flora. - Symb. Bot. Upsaliensis 29(3): 1-234.

MAhunka S. (1986): Oribatids from Africa (Acari, Oribatida) III. - Folia Entomol. Hung. 47(1-2): 41-76. 
Mahunka S. (1988a). The Oribatid fauna of Tanzania (Acari), I. - Acta Zool. Hung. 34(4): 345-378.

Mahunka S. (1988b): The Oribatid fauna of Tanzania (Acari), II. - Annls hist.-nat. Mus. natn. Hung. 80: 189-213.

MAHUNKA S. (1989): Preliminary study of the soil fauna of primary and secondary submontane rain forests on the East Usambaras. - In: Hamilton A. C. \& Bensted-Smith R. (eds): Forest conservation in the East Usambara Mountains Tanzania. IUCN The World Conservation Union, Tanzania, pp. 345-346.

Ochyra R. \& Pócs T. (1985): East African bryophytes, VIII. The Musci of the Usambara Rain Forest Expedition, 1982. - Acta Bot. Acad. Sci. Hung. 31: 135-146.

Pócs T. (1985): East African bryophytes, VII. The Hepaticae of the Usambara Rain Forest Project Expedition, 1982. - Acta Bot. Acad. Sci. Hung. 31: 113-133.

Pócs T. (1988): Check-list: Bryophyta of the Usambara Mountains. - In The SAREC supported Integrated Usambara Rain Forest Project, Tanzania. Report for the period 1983-1987. Uppsala-Morogoro, 14 pp.

Pócs T. (1989): A preliminary study of the undergrowth of primary and secondary submontane rainforests in the East Usambara Mountains, with notes on epiphytes. - In: HAMILTON A. C. \& BensteAD-SMith R. (eds): Forest conservation in the East Usambara Mountains, Tanzania. IUCN, Gland and Cambridge, pp. 301-306.

Pócs T. (1991a): Two new phanerogam species from the Nguru Mountains of Tanzania, East Africa. - Fragm. Flor. Geobot. 35: 35-41.

Pócs T. (1991b): Geography and ecology of Usambara's bryophytes. - In: HEdBerg I. \& Persson E. (eds): Research for conservation of Tanzanian catchment forests. - Proceedings from a workshop held in Morogoro, Tanzania, March 13-17, 1989. Uppsala, pp. 71-85.

Rodgers W. A. \& Homewood K. (2008): Species richness and endemism in the Usambara mountain forest, Tanzania. - Biol. J. Linnean Soc. 18(3): 197-242. https://doi.org/10.1111/j.1095-8312.1982.tb02037.x

Swinscow T. D. V. \& Krog H. (1986): Usnea antiqua sp. nov. described from Tanzania. - Lichenologist 18: 63-70. https://doi.org/10.1017/s0024282986000397

Swinscow T. D. V. \& Krog H. (1988): Macrolichens of East Africa. - British Museum (Natural History), London, $390 \mathrm{pp}$.

VERSEGHY K. \& FARKAS E. (1985): Untersuchungen der Luftverunreinigung im Gebiet von Budapest mit Hilfe der Flechtenkartierung als Indikatoren. - Ann. Univ. Sci. Budapest 24-26: 163-184.

VĚZDA A. (2004): Zur Systematik von Bacidia permira (foliicole Flechte, Asciomycetina). - Chech Mycol. 56(1-2): 149-150.

VĚZdA A. \& FARKAS E. (1988): Neue foliicole Arten der Flechtengattung Dimerella Trevisan (Gyalectaceae) aus Tansania. - Folia Geobot. Phytotax. 23: 183-197. https://doi.org/10.1007/bf02853348

ZICsi A. (1996): Neue und bekannte Regenwürmer (Oligochaeta) aus Ost-Afrika. - Mitt. Hamburg. Zool. Mus. Ins. 93: 17-37. 